\title{
The Situation of Food Security in Kazakhstan
}

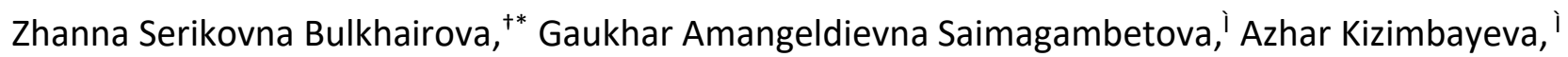

Gulzhiyan Maratovna Kadyrova,' and Sayassat Rahmetova Abdiyeva '̀

\section{Abstract}

The research aims to explore the current food security situation in the Republic of Kazakhstan. To accomplish this objective, the research examines some of the critical theoretical and practical aspects of food security in the nation. The findings reveal that when compared with other nations, in the period under analysis the food security level in Kazakhstan has increased reaching the world level. However, there remain many unresolved issues which are impeding progress. As part of the study, the authors conducted a survey by questionnaire designed to explore some of the key consumer motives and preferences underlying the choice of domestic or imported food products; assess the economic accessibility of food in a climate of rising prices and people's declining purchasing power; to examinewhether, as a result of the economic crisis (2015-2016), most people in Kazakhstan have opted for running a private subsidiary plot or for stocking up on food. The authors propose a model of the organisational structure underlying the process of implementation of Kazakhstan's strategy for boosting the competitiveness of the nation's agriculture and ensuring its food security.

Keywords: Food Security, Food Security Index, Affordability of Food Products, Quality and Safety of Food Products, Kazakasthan

\footnotetext{
${ }^{\dagger}$ S. Seifullin Kazakh Agro Technical University, 620Zhenis Avenue, Astana, 010011, Kazakhstan,

${ }^{*}$ Corresponding Author, Email: honeyzhu@mail.ru

' Yessenov University, 32 Microdistrict, Aktau, 130003, Kazakhstan

(C) 2019 Bulkhairova et al. This is an Open Access article distributed under the terms of the Creative Commons Attribution License (http://creativecommons.org/licenses/by/2.0), which permits unrestricted use, distribution, and reproduction in any medium, provided the original work is properly cited.
} 


\section{Introduction}

Based on the latest estimates from the Food and Agriculture Organisation(FAO) of the United Nations, in recent years the world has seen an increase in the proportion of the world's population who are undernourished the Prevalence of Undernourishment (PoU) indicator\}. In 2017, the figure reached $10.9 \%$, the absolute number of undernourished people around the world growing between 2016 and 2017 from close to 804 million to nearly 821 million. This trend may serve as a clear exhortation that all nations around the world should devote special attention to issues of food security (FAO et al., 2018). Keeping in line the importance of food security and the call of FAO, the Journal Space and Culture, India too has published different research on this issue (Bezbaruah, 2013; Nandi and Mistri, 2019; Siddique \& Mukherjee, 2017; Zhupley et al., 2018).

Similarly, in the current climate of innovationfocused development, Kazakhstan is increasingly focused on issues of food security. The central issues linked to food security greatly deals with the nation's ability to be self-sufficient in providing its population with food, that is, a keen focus on the development of the agricultural sector and cultivation of agricultural protectionism. As of 1 November 2017, the total area of land under agriculture in the Republic of Kazakhstan is $104,050.6$ thousand ha (39.7\%). These lands receive special legal treatment and are protected in terms of restrictions on their use for other purposes and a focus on maintaining and boosting their fertility levels. In recent years, agricultural land has expanded across the nation as a result of reclamation of undistributed lands, its total area increasing by 1.5 million ha (Ministry of Agriculture of the Republic of Kazakhstan, 2018).

Kazakhstan has managed to achieve reliable levels of food security owing to its ability to ensure the right volumes of food production, the right level of innovation-focused development of the production process, and the availability of funding for food imports; while demonstrating low vulnerability levels in terms of food supply due to certain complications or irregularities in interstate food supply (an embargo). A crucial role in ensuring food security and fostering its sustainable development in the future is played by agriculture. In his message to the people of Kazakhstan, delivered on 10 January 2018, President N.A. Nazarbaev stated that "agricultural policy ought to be aimed at boosting labour productivity and exports of processed agricultural produce... The nation ought to ensure the ability to process raw materials in innovative ways, and, with a highquality end product in hand, seek entry into global markets... Comprehensive support ought to be provided to agri-cooperatives" (A Message from the President of the Republic of Kazakhstan, 2018).Issues related to achieving sustainable food security levels are among the more researched ones (Bezbaruah, 2013; Bickel et al. (2000); FAO et al., 2018; Food Security Act of 1985, 2018; Nandi and Mistri, 2019; Siddique \& Mukherjee, 2017; Zhupley et al., 2018) around the world, including in Kazakhstan. The nation's food security levels depend, above all, on the current condition of its agro-industrial complex. At the moment, Kazakhstan's agricultural sector is characterised by the following: a decline in the fertility of land resources; a worsening materialtechnical base in the agricultural sector; low crop yields; and low livestock output (Kulikova, 2014; Bulkhairova et al., 2016; 2018). Accordingly, the subject requires a more in-depth and thorough investigation, as the food market is subject to continual change and its operation depends on a variety of factors. Thus, based on the above, it may be stated that the topic of food security in Kazakhstan is a relevant subject that needs to be researched further.

The research begins with a brief review of the literature. Following this, we discuss the methods that have been deployed to accomplish our results. The findings are discussed in the section following the methods.

\section{Literature Review}

Today, most of the theoretical and practical aspects of assessing and ensuring food security 
are investigated by scholars at the global, national, and regional levels, as well as at the level of particular households.

Developed countries, like the US, Germany, France, and Japan, attach great significance to the need to resolve the issue of food security. While all of these nations tend to approach the issue from the standpoint of high levels of food self-sufficiency achieved by them, there are specific differences in the way the different countries view food security. For instance, in Germany food security, as one of the major issues on the national agenda, is normally brought up only when it is impossible to make appropriate adjustments through regulating the market. Inherently, Germany tends to tackle the issue mainly in the context of the emergence of a recessionary situation in the country. In the US, food security is thought of in the context of (1) sustaining the stability of sales in the internal market for food (a focus on national production), (2) implementing a program of food assistance for the low-income, and (3) stimulating agricultural exports and the use of food exports in the interests of the nation's foreign policy (Food Security Act of 1985, 2018).

A different approach is pursued by Russia, Kazakhstan, Uzbekistan, and some other nations, which formally approach the issue of food security as a means of resolving the issue of providing the population with essential food products, with a concurrent focus on food quality and food affordability. However, the major focus is on the issue of attaining food selfsufficiency, with the government specifically focused on the absolute size of the production of essential food products within the actual nation (Decree of the President of the Russian Federation No. 120, 2010).

While there may be individual differences in scholarly approaches to issues of food security in different nations, what is common to all of them is the tenet that all people around the world must enjoy equal rights to the amount of food that is sufficient to preserve further and maintain their health (Rakhimzhanova, 2015). Scholar L.S. Cheshinskii construes food security as "...ensuring the guaranteed satisfaction of the need for essential food products (in alignment with generally accepted nutrition standards) mainly through domestic production, with a focus on the safety of food and its economic affordability" (Cheshinskii, 1997: 6). The scholar links a person's specific needs with generally accepted nutrition standards and focuses on food's qualitative component.

V.G. Loginov incorporates two additional aspects into the definition of food security: the role of the state and society and emergencies. The scholar defines food security as "...the timeunrestricted ability of the state and society to provide the population with access to quality food in quantities that are sufficient for the healthy physical and social development of each individual under regular conditions and minimally enough to maintain a person's health and working capacity in emergency situations" (Loginov, 2002: 21).

In their 'Guide to Measuring Household Food Security', scholars G. Bickel, M. Nord, C. Price, W. Hamilton, and J. Cook describe food security as "a complex, multidimensional phenomenon which varies through a continuum of successive stages as the condition becomes more severe. Each stage consists of characteristic conditions and experiences of food insufficiency to fully meet the basic needs of household members, and of the behavioural responses of household members to these conditions. A variety of indicators is needed to capture the various combinations of food conditions, experiences, and behaviours that, as a group, characterise each such stage" (Bickel et al., 2000: 13).

Thus, food security is a fundamental, backbone part of national security which interacts with and penetrates all of its areas and serves as a basis for other types of security. A nation's nutrition and food affordability levels characterise the level of its economic development as a whole. The availability of food, including owing to its regular production by domestic agricultural producers, is a necessary condition for meeting people's need for diverse product ranges and high-quality food products. The research aims to critically assess the current food security 
situation in the Republic of Kazakhstan. The methods are discussed in the following section.

\section{Methods}

To assess the latest levels of food security, a set of special metrics have been employed at the level of world organisations. Some of these gauges were brought forward in the Concept on Food Security in the Eurasian Economic Community (The Concept on Food Security, 2009) and the Concept on Boosting Food Security in the CIS Member States (CIS Council of Heads of Governments, 2010).

The Global Food Security Index assesses the policies of the nations around the world and the efficiency of work done by their relevant institutions with regard to food security. The index is derived from research that covers 113 countries and measures the level of food security based on the following three key parameters: affordability of food, availability of food, and the quality and safety of food (Global Food Security Index, 2018).

In conducting this research, the authors also employed a tool of their own - an online survey by questionnaire. The survey engaged 1,831 individuals, aged $20-80$, residing in rural areas and cities in the Akmola Region and the city of Astana. Astana is the capital of Kazakhstan, and the Akmola Region is the closest to it. It is one of the republic's top regions in crop farming and is the primary supplier of agricultural produce to Astana. Currently, 128 agricultural enterprises are operating in the region, with 68 of them focused on livestock farming (meat and meat products and milk and dairy products), 6 - on poultry (chicken and eggs), and 54 - on crop farming (flour, potatoes, vegetables, and vegetable oil). In the period between January and September of 2018, the region's Gross Agricultural Output was valued at $334,451.7$ million tenges (crop farming - 230,669.4 million tenge and livestock farming $-102,654.5$ million tenges). The index of the physical volume of gross agricultural output was $100.0 \%$, with the index of the physical volume of crop farming output in the region coming in at $98.5 \%$, and that of livestock farming output - at $103.6 \%$ (Official Internet Resource for Akmola Region, n.d.).
The survey was comprised of the following blocks: food purchasing characteristics (assessments of perceived changes in the product range at stores, assessments of the degree to which a person is restricting themselves in the purchase of food, assessments of a person's choice of where to buy, and assessments of what a person may do if there is a rise in prices); prices (assessments of how much of the family budget goes to food and of the choice of food products depending on the rise in prices); additional sources of food for households (growing vegetables and fruits; assistance from relatives).

The survey aimed to explore some of the key consumer motives and preferences underlying the choice of domestic or imported food products; assess the economic accessibility of food in a climate of rising prices, and people's declining purchasing power; to find out whether, as a result of the economic crisis (2015-2016), most people in Kazakhstan had opted for running a private subsidiary plot or for stocking up on food.

\section{Results and Discussion}

Today, Kazakhstan possesses substantial potential for the development of the agroindustrial complex and provision of its population with virtually all types of food in keeping with generally accepted food-ration standards. However, the current level of the nation's economic development, which mainly is founded on the use of traditional technology in the production process, including the processing of raw materials, is not high enough to meet the requirements and needs of the international market, which is a factor impeding robust development in the republic. This is affecting the competitiveness of products produced domestically, which do not entirely match the latest requirements set by global markets, while there is little demand for the scientifictechnological potential of the nation's agricultural science, with its overall food security levels declining as a result (Law of the Republic of Kazakhstan No. 301-III, 2007; Kendiukh,2004) 
Table 1: 2018 Global Food Security Rankings

\begin{tabular}{|c|c|c|c|}
\hline Rank & Country & Index & $\begin{array}{c}\text { Change from } 2018 \text { to } 2017 \\
(+/-)\end{array}$ \\
\hline 1 & Singapore & 85.9 & +0.9 \\
\hline 2 & Ireland & 85.5 & -1.2 \\
\hline$=3$ & United Kingdom & 85.0 & +0.6 \\
\hline$=3$ & United States & 85.0 & +0.1 \\
\hline 5 & Netherlands & 84.7 & +1.6 \\
\hline 6 & Australia & 83.7 & +0.2 \\
\hline 7 & Switzerland & 83.5 & +0.6 \\
\hline 8 & Finland & 83.3 & +2.0 \\
\hline 9 & Canada & 83.2 & +0.7 \\
\hline 10 & France & 82.9 & +0.4 \\
\hline 11 & Germany & 82.7 & -0.1 \\
\hline$\ldots$ & $\ldots$ & $\ldots$ & $\ldots$ \\
\hline 42 & Russia & 67.0 & 0.8 \\
\hline$\ldots$ & $\ldots$ & $\ldots$ & $\ldots$ \\
\hline 57 & Kazakhstan & 57.7 & +1.8 \\
\hline
\end{tabular}

Note. Compiled by the Authors Based on Data from the Source-Global Food Security Index, 2018

Table 1 illustrates the level of development of food security around the world in 2018. As is evidenced in Table 1, in 2018 Kazakhstan managed to move in the world food security rankings from 60th to 57th place (its 2017 rank); its current food security index is 57.7, an increase of 1.8 points on 2017. Also, Kazakhstan is currently behind Russia in these rankings, which is 42 nd at the moment. Below is a detailed analysis of some of the critical parameters of food security around the world, including in Kazakhstan, as of 2018 (Figure 1). It is apparent from Figure 1 that in the period 2012-2018 Kazakhstan has posted an improved food security level (Figure $1 \mathrm{~A}$ ) vis-à-vis the rest of the nations within the Asia-Pacific region, almost reaching the world level in 2018. This improvement is due to boosts in the nation's food affordability level (Figure 1B), which has even surpassed the world level and boosts in the level of quality and safety of food products in 2018, with the nation reaching the average world level in the area. At the same time, it is worth noting that in the period under analysis, Kazakhstan has lagged behind the world level in food availability.
It is time now to examine and analyse the level of food security in Kazakhstan based on the findings from the authors' questionnaire-based survey with the residents of rural areas of Akmola Region and the city of Astana. The survey data were duly processed and grouped to ensure maximum consistency.

It may be worth starting the analysis of the nation's food security with the differences in retail trade depending on one's place of residence (Figure 2). Evidently (Figure 2), most of the respondents deemed that at the time the survey was conducted domestic products were greater in number than imported ones at supermarkets in their area of residence: Akmola Region's rural residents - 56\%, Akmola Region's urban residents $-47 \%$, and residents of the city of Astana - 31\%. Also, the survey revealed that most of the participants shopped at the following places: large supermarkets $-59 \%$, and small ones $-41 \%$, considering that one in two respondents (48\%) shopped at food markets. The majority of the $8 \%$ whose answer was 


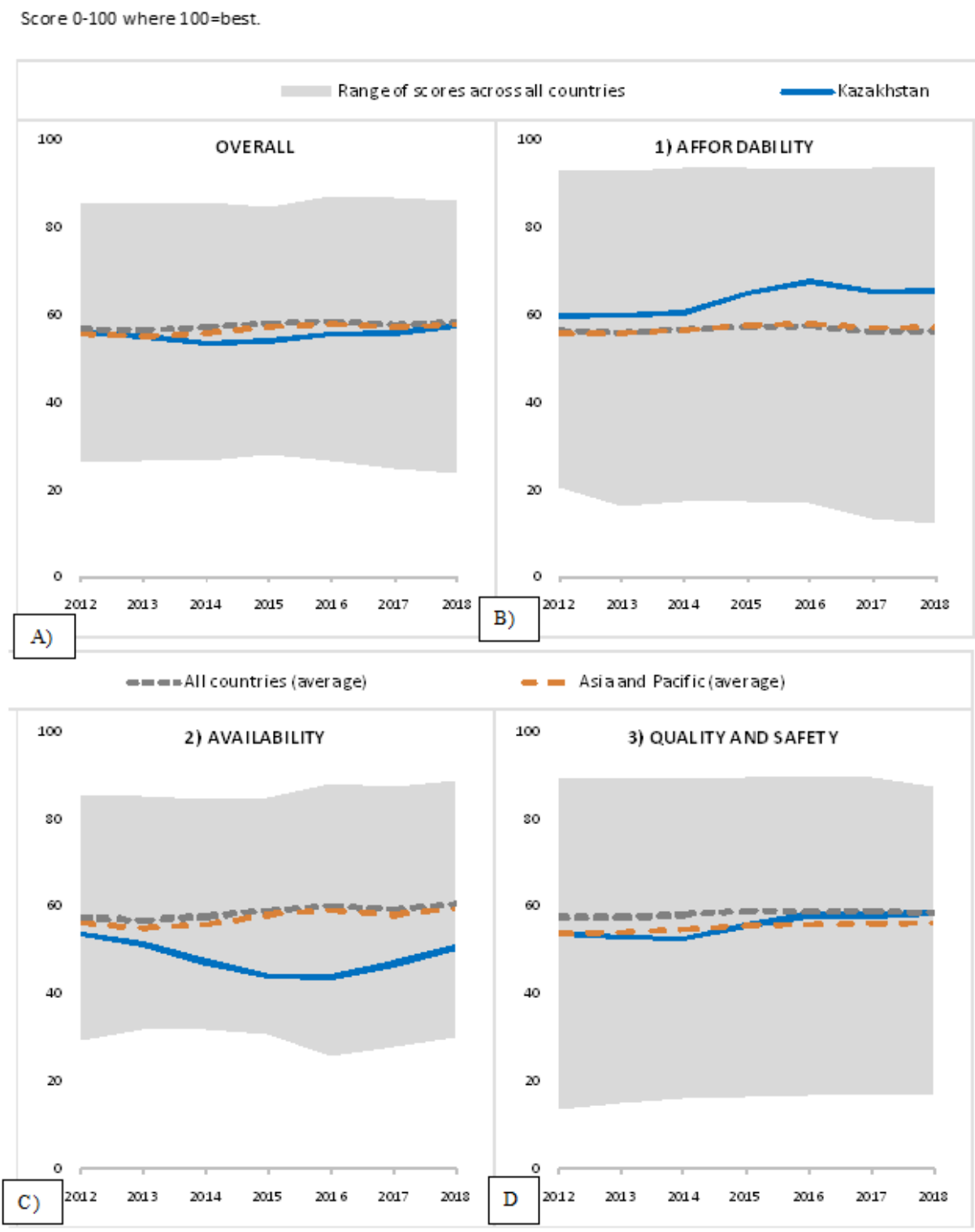

Figure 1: Food Security Levels in Kazakhstan and Other Nations Around the World Source: Compiled by the Authors Based on Data From the Source-Global Food Security Index, 2018.

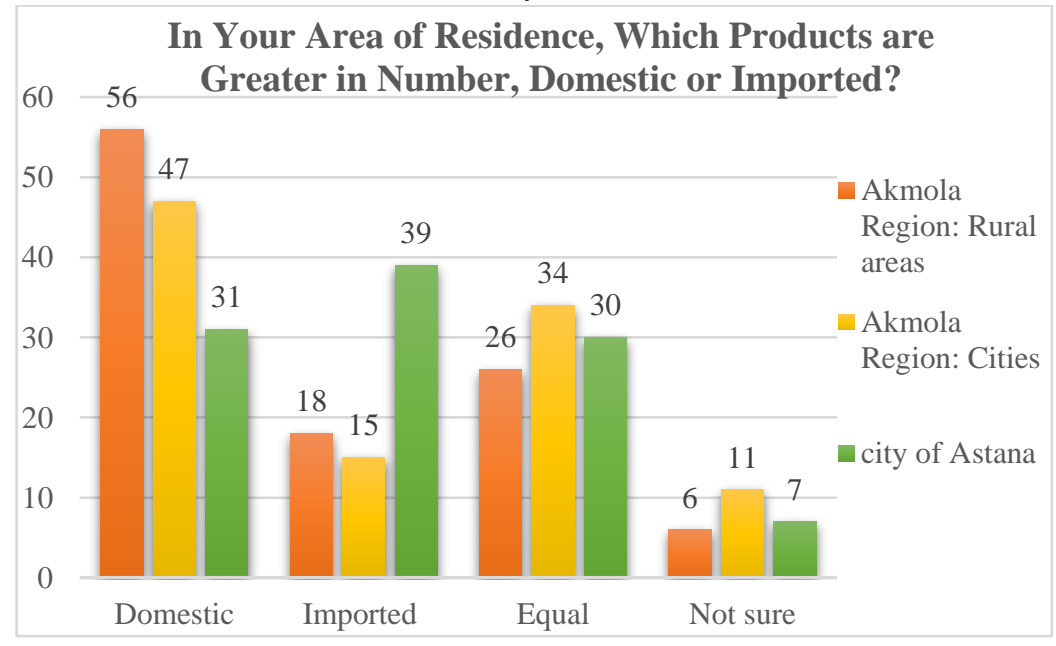

Figure 2: Differences in Retail Trade Depending on one's Place of Residence (in Percentage) Source: Compiled by the Authors. 


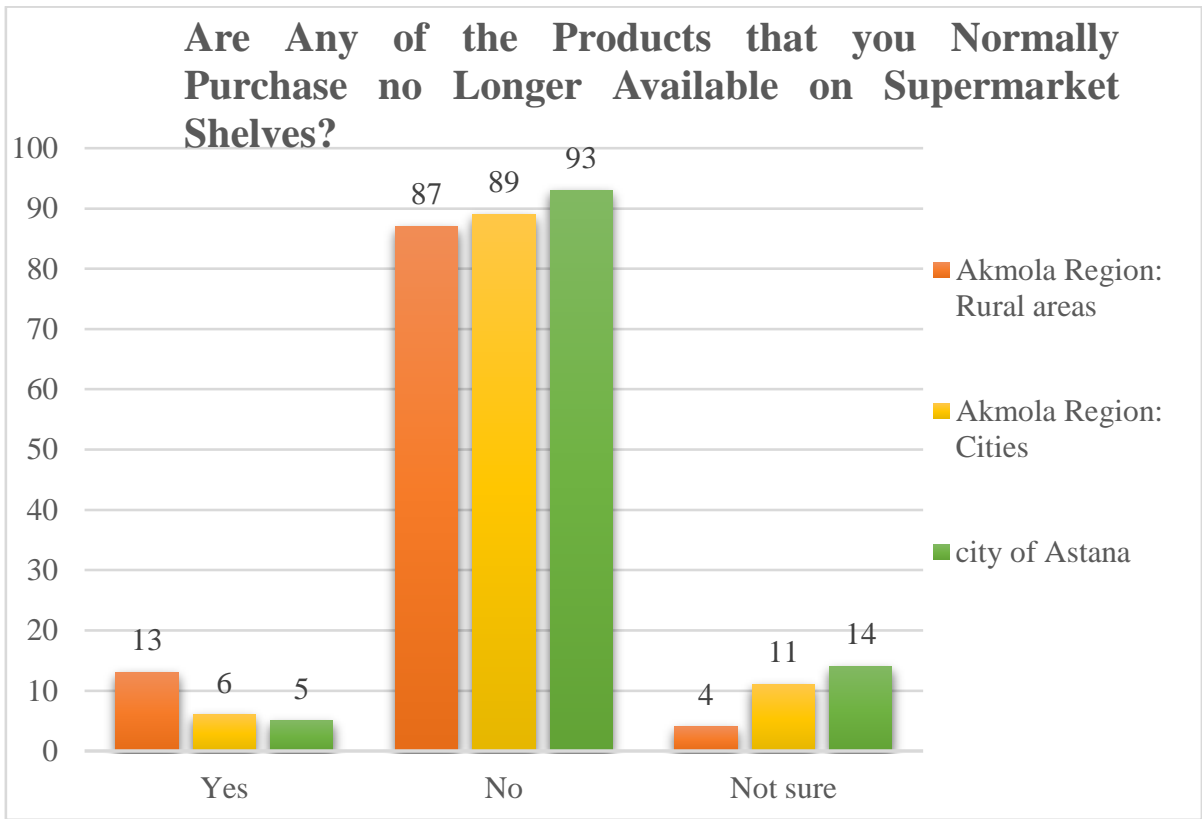

Figure 3: Decline in the Product Range (in Percentage).

Source: Compiled by the Authors.

'Other' (74\%) said they shopped at wholesale depots and warehouses. Let us now examine the declines in the product range (Figure 3 ). $87 \%$ of the respondents are rural residents of Akmola Region, $89 \%$ of the respondents are urban residents of Akmola Region, and 93\% of the respondent, who lived in the city of Astana confessed to not having registered the disappearance of certain regular products from the supermarket shelves, with those who did mentioning dairy products (e.g., cheese) and fruits, mainly (Figure 3). In 2017, versus 2016, there was an increase in the consumption levels across essential food products, except for vegetables, fish and seafood, and potatoes. The consumption of significant food products such as bread and cereals increased by $2.3 \%$, milk and dairy products $-0.9 \%$, and meat and meat products $-0.1 \%$. The average monthly per capita consumption of essential food products in 2017 was as follows: rice $-1.3 \mathrm{~kg}$, wheat bread made from first grade flour $-3.7 \mathrm{~kg}$, macaroni $-1 \mathrm{~kg}$, beef $-2 \mathrm{~kg}$, fresh or frozen fish $-0.6 \mathrm{~kg}$, raw milk - 1.7 L, buttermilk - 1.2 L, eggs - 14 pieces, apples $-1.3 \mathrm{~kg}$, potatoes $-3.9 \mathrm{~kg}$, granulated sugar $-1.7 \mathrm{~kg}$, and black tea $-0.2 \mathrm{~kg}$ (Kazakh Telegraph Agency, 2018).

It is, also, worth taking into account that $61 \%$ of Akmola Region's rural and $59 \%$ of its urban residents and $56 \%$ of the city of Astana's residents confessed to having restricted themselves in the purchase of food due to the rise in prices, with $26 \%, 37 \%$, and $43 \%$, respectively, confessing to not having done so and very few respondents being undecided (4$9 \%$ ) (Figure 4). Because of the rise in prices, majority of them have stopped buying meat (57\%), fish (49\%), candy and sweets (57\%), and fresh vegetables and dairy products (37\%).

It is also worth noting that, when comparing rural and urban residents in terms of their consumption of essential food products, one may notice the most significant degree of differentiation when it comes to eggs, as well as fruits, bread and cereals products, and milk and dairy products (Kazakh Telegraph Agency, 2018). 


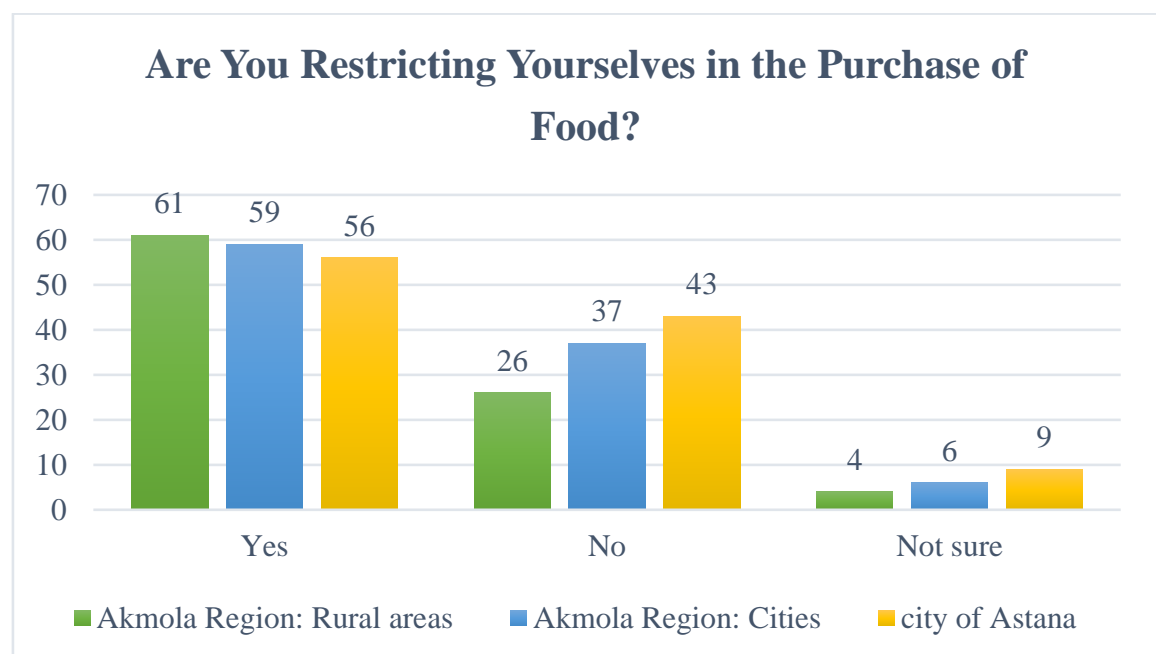

Figure 4: Restricting Oneself in the Purchase of Food (Figures in Percentages) Source: Compiled by the Authors.

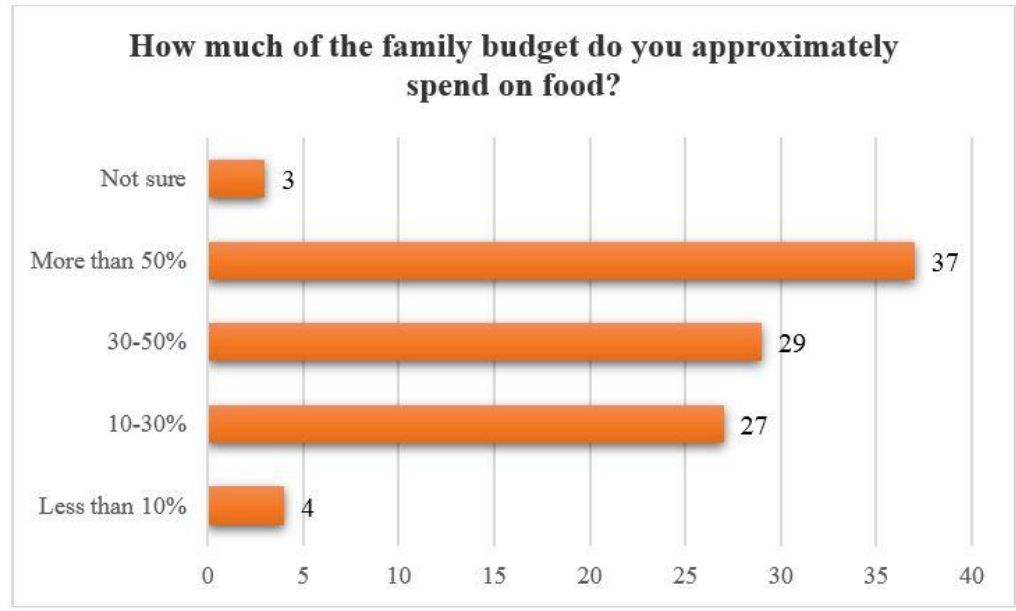

Figure 5: The Share of the Family Budget Devoted to Food (in Percentage). Compiled by the Authors

At the time the survey was conducted, the population's expenditure on food was as follows: $37 \%$ - over $50 \%$ of the family budget, $29 \%-30-50 \%$ of the family budget, and $27 \%-$ $10-30 \%$ of the family budget (Figure 5 ). It is to be noted that among the respondents there were some $=$ rural residents, who were increasingly focused on growing vegetables and fruits and keeping poultry or livestock on their own. It was also revealed that with the prices continuing to rise, $43 \%$ of the respondents were increasingly opting to and trying to grow their own produce in a kitchen garden (at a dacha), rather than stocking up on it (7\%), with most of the respondents (80\%) helping their relatives with money or homemade food items made from kitchen-garden produce, and, apparently, hopeful of getting the same type of assistance in return as well ( $60 \%$ confessing to having already received that type of assistance). Most of the time, assistance was said to be provided by rural residents to urban ones in the form of homemade food items and homegrown produce (mainly, to children who live in the city or adults who were visited by their relatives, who may bring them food items as a gift). 


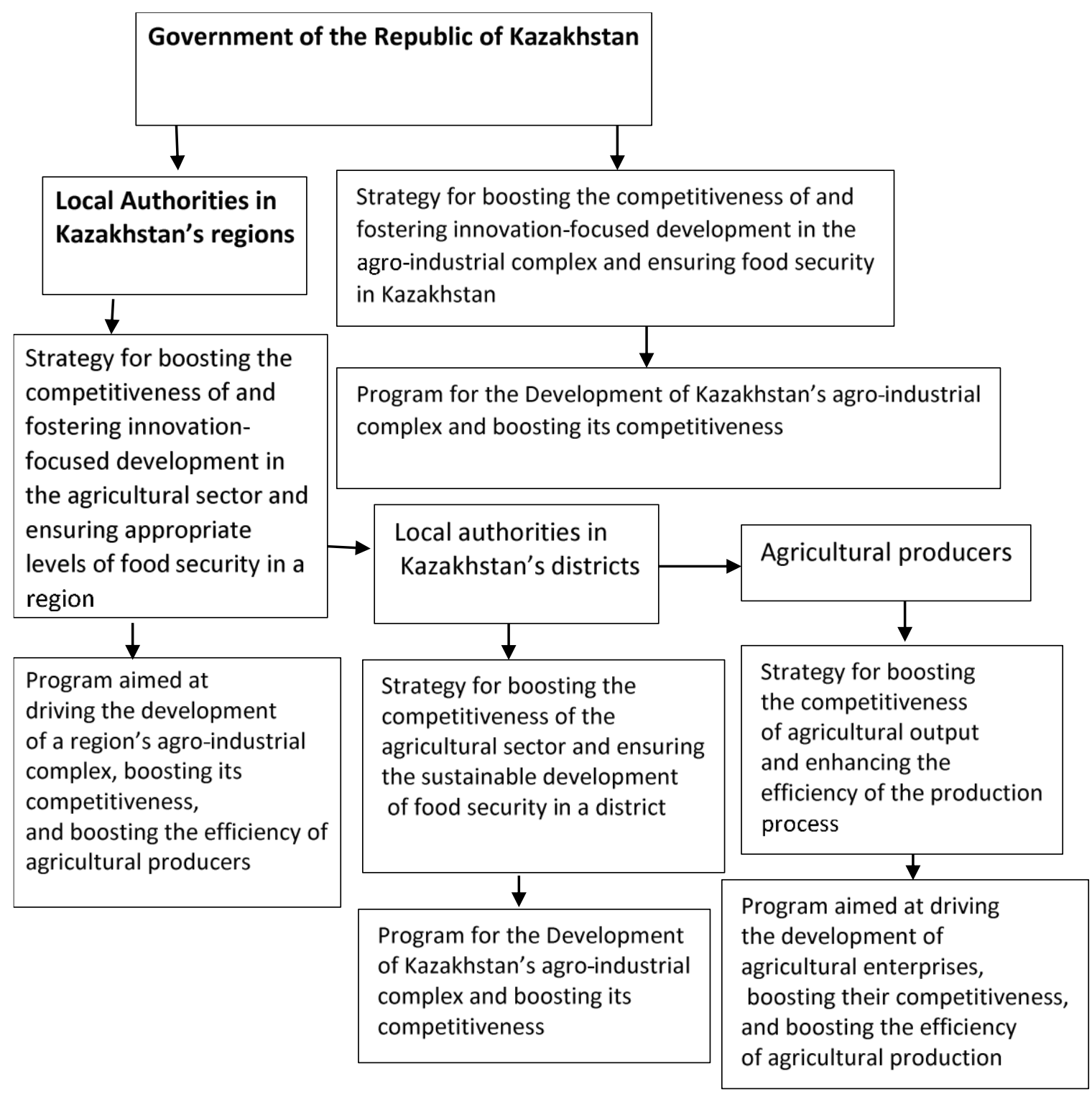

Figure 6: Model of the Organisational Structure Underlying the Process of Implementation of Kazakhstan's strategy for Boosting the Competitiveness of Agriculture and Ensuring Food Security.

Source: Compiled by the Authors

Thus, based on the statistical information provided above, the nation's food security, is based in the consideration of rise in prices, has yet to reach an optimal level and there is a need to adopt appropriate measures to boost it. In a climate of innovation-focused development, one of the potential areas of greatest promise in the context of ensuring food security in Kazakhstan is implementing a proper strategy, that is, developing a set of appropriate measures, aimed at boosting the competitiveness of the nation's agro-industrial complex (Figure 6).

Based on Figure 6, in a situation where there is a stiffening of competition in the local markets for food, particular importance should be given to concentrating the resources on the domestic level. Along with experimental, pedigreebreeding, and selection centres, which can help ensure appropriate genetic pool levels in agricultural production, to boost the 
competitiveness of the agro-industrial complex a significant focus ought to be on agricultural entities in districts and regions that are situated in more favourable natural-climatic conditions and employ the latest resource-saving technology. This would enable agri-producers that are already doing well in business to accumulate financial resources with a greater effect and better end result (Kendiukh, 2014).

\section{Conclusion}

In today's climate of increased focus on innovation-driven development, every nation that is willing to pursue an independent and effective domestic and foreign policy ought to, above all, focus on its food security, which implies sufficient food quantities, a sustainable supply of food, and, what is most important, the affordability of food products (Bezbaruah, 2013; Bickel et al. (2000); FAO et al., 2018; Food Security Act of 1985, 2018; Nandi and Mistri, 2019; Siddique \& Mukherjee, 2017; Zhupley et al., 2018).

Today, food security may, in essence, and significance, be equated to physical security, which guarantees the survival of people, as it is the food products that are among their vital needs, which must be met for them to be able to function properly. A key objective and priority for the state's policy in most nations are to maintain the right level of food security. An important thing to remember is that losing control over the nation's food security situation in the short run may affect domestic sovereignty and make the nation vulnerable to the impacts of socio-economic, financial, and political pressure on the part of other nations.

The key conditions for being able to achieve food security in a nation include: the right amounts of food being available to its population; the production process being focused on innovation; food being affordable to various social groups of the population, including disadvantaged and vulnerable citizens; citizens being able to consume quality food in quantities that are sufficient for rational diets.

A significant condition for Kazakhstan and its regions to be able to achieve food security is via the creation of the conditions for the further development of the potential to steadily provide the population with food regardless of internal and external challenges. The nation's focus on ensuring and fostering sustainable levels of food security ought to be implemented at all levels of government - republican, regional, and district, and among all agricultural entities in the republic. These efforts must incorporate all areas that could be aimed at boosting the competitiveness of the nation's agricultural sector and agro-industrial complex, the calibre of its production processes, the quality of its agricultural products and services, and the efficiency of its agricultural entities.

\section{References}

Bezbaruah, M. (2013). A Discussion in Light of India's National Food Security Act. Space and Culture, India, 1(2), 3-11. https://doi.org/10.20896/saci.v1i2.25

Bickel, G., Nord, M., Price, C., Hamilton, W., \& Cook, J. (2000). Guide to measuring household food security. Alexandria, VA: USDA Food and Nutrition Service.

Bulkhairova, Zh. S., Alenova, K. T., Nukesheva, A. Zh., \& Ismailova, A. S. (2016). Assessment of human capital in the agricultural enterprises of the Republic of Kazakhstan. International Journal of Economics and Financial Issues, 6(S5), 53-64.

Bulkhairova, Zh. S., Imashova, Z. D., Nurtayeva, Zh. Sh., Taskinbaikyzy, Zh., \& Yerkulova, G. S. (2018). The current state of affairs with regard to the effective management of human capital in agricultural enterprises. Journal of Applied Economic Sciences, 13(4), 1095-1100.

Cheshinskii, L. S. (1997). Metodologiya problemy prodovolstvennoi bezopasnosti [A methodology on the issue of food security]. Khlebopechenie Rossii, 4, 6-8.

CIS Council of Heads of Governments. (2010). Reshenie o Kontseptsii povysheniya prodovolstvennoi bezopasnosti gosudarstvuchastnikov SNG [Decision on the Concept on Boosting Food Security in the CIS 
Member States]. Retrieved February 8, 2019 from http://e-

cis.info/foto/pages/20000.doc.

Economist Intelligence Unit: Reiting stran mira po urovnyu prodovolstvennoi bezopasnosti v 2016 godu [Economist Intelligence Unit: The Global Food Security Index 2016]. (2016). Retrieved February 8, 2019 from https://gtmarket.ru/news/2016/01/29/729 1.

FAO, IFAD, UNICEF, WFP, \& WHO. (2018). The state of food security and nutrition in the world - 2018. Building climate resilience for food security and nutrition. Retrieved February 8, 2019 from http://www.fao.org/in-action/fsn-caucasusasia/resources/detail/en/c/1154024/.

Food Security Act of 1985, 16 U.S.C. §§ 38013862. (2018).

Global Food Security Index. (2018). https://foodsecurityindex.eiu.com/Index Kazakh Telegraph Agency. (2018). V ratsione kazakhstantsev po-prezhnemu malo ovoshchei, ryby i moreproduktov - statdannye [Diets in Kazakhstan are still poor in vegetables, fish, and seafood Statistical data]. Retrieved February 8, 2019 from https://www.kaztag.kz/ru/news/v-ratsionekazakhstantsev-po-prezhnemu-maloovoshchey-ryby-i-moreproduktov-statdannye.

Kendiukh, E. V. (2014). Obespechenie prodovolstvennoi bezopasnosti strany na osnove povysheniya konkurentosposobnosti APK: Teoriya, metodologiya, praktika (na materialakh Respubliki Kazakhstan)

[Ensuring a nation's food security based on boosts in the competitiveness of its agroindustrial complex: Theory, methodology, and practice (the case of the Republic of Kazakhstan)] (unpublished candidate's thesis). Novosibirsk, Russia: Siberian Agriculture Economics Institute.

Kontseptsiya prodovolstvennoi bezopasnosti Evraziiskogo ekonomicheskogo soobshchestva. Prilozhenie k Resheniyu Mezhgossoveta EvrAzES ot 11 dekabrya
2009 g. № 464 [The Concept on Food Security in the Eurasian Economic Community. An addendum to the Decision of the Interstate Council of the Eurasian Economic Community No. 464 of December 11, 2009]. (2009). Retrieved February 8 , 2019 from

http://www.businesspravo.ru/Docum/docu mshow_documid_180200.html.

Kulikova, L. V. (2014). Prodovolstvennaya bezopasnost: Problemy i napravleniya obespecheniya [Food security: Issues in and areas for ensuring it]. Vestnik Tverskogo Gosudarstvennogo Universiteta. Seriya: Ekonomika i Upravlenie, 1, 226-233.

Loginov, V. G. (2002). Selskoe khozyaistvo i regulirovanie prodovolstvennykh rynkov. Vlast, biznes i krestyanstvo: Mekhanizm effektivnogo vzaimodeistviya [Agriculture and regulation of food markets. The authorities, business, and peasantry: $A$ mechanism for their effective interaction]. Moscow, Russia: Entsiklopediya Rossiiskikh Dereven.

Ministry of Agriculture of the Republic of Kazakhstan. (2018). Svodnyi analiticheskii otchet. O sostoyanii $i$ ispolzovanii zemel Respubliki Kazakhstan za 2017 god [The condition and use of lands in the Republic of Kazakhstan in 2017: A consolidated analytical report]. Retrieved February 8, 2019 from mgov.kz/wpcontent/uploads/2018/avgust/25.08/kuzrot chet.pdf.

Nandi, S. and Mistri, T. (2019). Rural Settlement Expansion and its Effect on Food Security in Salanpur, West Bengal, India, Space and Culture, India 6(5),https://doi.org/10.20896/saci.v6i5.346

Official Internet Resource for Akmola Region. (n.d.). Tekushchaya informatsiya o sostoyanii otrasli [Current information on the sector's condition]. Retrieved February 8, 2019 from http://aqmola.gov.kz/page/read/Tekucshay a_informaciya_o_sostoyanii_otrasli_selhoz. html?lang=ru. 
Poslanie Prezidenta Respubliki Kazakhstan N. Nazarbaeva narodu Kazakhstana [A message from the President of the Republic of Kazakhstan N. Nazarbaev to the people of Kazakhstan]. (2018). Retrieved February 8, 2019 from http://www.akorda.kz/ru/addresses/addres ses_of_president/poslanie-prezidentarespubliki-kazahstan-n-nazarbaeva-narodukazahstana-10-yanvarya-2018-g.

Rakhimzhanova, G. M. (2015). Prodovolstvennaya bezopasnost Kazakhstana i prioritety ee obespecheniya [Food security in Kazakhstan and priorities for ensuring it] (unpublished doctoral dissertation). Almaty, Kazakhstan: Turar Ryskulov New Economic University.

Siddique, G., \& Mukherjee, N. (2017).

Transformation of Agricultural Land for Urbanisation, Infrastructural Development and Question of Future Food Security: Cases from Parts of Hugli District, West Bengal. Space and Culture, India, 5(2), 4768. https://doi.org/10.20896/saci.v5i2.269
Ukaz Prezidenta Rossiiskoi Federatsii ot 30 yanvarya $2010 \mathrm{~g}$. N 120 "Ob utverzhdenii Doktriny prodovolstvennoi bezopasnosti Rossiiskoi Federatsii" [Decree of the President of the Russian Federation No. 120 "On Signing into Law the Doctrine on Food Security in the Russian Federation" of January 30, 2010]. (2010). Retrieved February 8, 2019 from https://rg.ru/2010/02/03/prod-dok.html.

Zakon Respubliki Kazakhstan ot 21 iyulya 2007 goda № 301-III "O bezopasnosti pishchevoi produktsii" [Law of the Republic of Kazakhstan No. 301-III "On Food Safety" of July 21, 2007]. (2007). Retrieved February 8, 2019 from https://online.zakon.kz/document/?doc_id $=30114108$ \#pos=3;-170.

Zhupley, I., Potenko, T., Gubarkov, S., Tretyak, N., \& Grafov, R. (2018). Structural Shifts and Reform of the Agrarian Sector of the Russian Economy under the Conditions of the Import Substitution Policy. Space and Culture, India, 6(4), 25-35. https://doi.org/10.20896/saci.v6i4.385 